\title{
"Socialism of the 21st Century" in Latin American Countries:Major Challenges and Prospects
}

\author{
Rong Shu * \\ School of Marxism \\ Zhongnan University of Economics and Law \\ Wuhan, P.R.China, 430073 \\ E-mail: rongshu1987@126.com
}

\author{
Dong Xiaofan \\ School of Marxism \\ Zhongnan University of Economics and Law \\ Wuhan, P.R.China, 430073
}

\begin{abstract}
The Socialism of the 21st century in Latin American countries, a result of long-standing political, economic and social contradictions, was put forward by President Hugo Chavez to reform the country. As an overall development strategy, "Socialism of the 21 st century" is a breakthrough for developing countries to get rid of the "Washington Consensus" and Western model, its exploration and practice has epochmaking significance. However, there are no established procedures to fulfill the construction of the "Socialism of the 21st century" in Venezuela and other Latin American countries within a certain period of time. The Chavez government pushed forward the socialist cause through the trial and error process, facing challenges to resolve the conflicts between short-term and long-term interests and achieving the balance between social equity and economic efficiency.
\end{abstract}

Keywords-Socialism of the 21st century; Latin American; Challenges; Prospects

\section{INTRODUCTION}

In recent years, affected by the political system, political environment, policy, economic and the external environment condition, "Socialism of the 21st century" in Latin America faces a series of severe challenges, the drastic changes of the world situation pressured the Latin American regions, the political and social forces in Latin America have changed significantly. The left-wing ruling party's ruling pressure increase, the practice of "Socialism of the 21st century" in Venezuela and other countries facing a lot of difficulties, their future are uncertain. In response to the new challenges, Latin American advocates of "21st-century socialism" put forward some new ideas and continue to advance their explorations in different ways. Its practice will not be smooth, and its prospects have greater uncertainty.

\section{EASE OF USE}

\section{A. The current situation of "Socialism of the 21st century" in Latin America countries.}

Socialism of the 21st century (Spanish: socialismo del siglo XXI) is a political term used to describe the interpretation of socialist principles advocated first by 'Heinz Dieterich in

This project funded by the Basic Scientific Research for HEIs under the Ministry of Education in China "Socialism of the 21st century in Latin American countries: current situation and Prospects" (NO.17YJC7100067); "The Basic Scientific Research Operational Funds for HEIs under the Ministry of Education in China"(NO.31541311804)
1996 and later by Latin American leaders like Hugo Chávez of Venezuela, Rafael Correa of Ecuador, Evo Morales of Bolivia and Luiz Inácio Lula da Silva of Brazil."[1] Former Venezuelan President Hugo Chávez has called the process of socialist reforms in Venezuela the "Bolivarian process". It is more heavily influenced by the theories of Mészáros, Lebowitz and Harnecker (who was Chávez's adviser between 2004 and 2011) than by those of Dieterich. Socialism of the 21st century argues that both free market industrial capitalism and twentieth-century socialism have failed to solve urgent problems of humanity, like poverty, hunger, exploitation, economic oppression, sexism, racism, the destruction of natural resources and the absence of a truly participative democracy. Therefore because of the local unique historical conditions, socialism of the 21st century is often contrasted with previous applications of socialism in other countries and aims for a more decentralized and participatory planning process. Socialism of the 21st century has democratic socialist elements, but primarily resembles Marxist revisionism.

With the changes in the economic situation, the advocate of the "socialism in the 21st century" did not abandon the socialist idea, reaffirmed their basic principles and direction, put forward some new ideas and new elaborations. Venezuela reaffirms the direction of socialism. Mr. Maduro has stressed that he will "Continue to carry out the socialism in the 21st century, and replace the destructive and barbaric capitalist system with socialism'[2]. In 2014, the ruling party held the "The third congress", repeated to build a "socialist economy", confirm the anti-capitalist properties, and stressed that set up a mode of "Socialism of the 21st century" is a historic work.

Ecuador proposes the idea of "modern socialism". After 2014, President Rafael Correa frequently referred to the "modern socialism", he thought enriched the "socialism in the 21st century". Mr. Correa reiterated that "neoliberalism had suffered a crushing defeat in Latin America, and socialism was the only road to Latin America's development. There is no better alternative than socialism," [3] Correa believes that the core of "modern socialism" is to combine the market and the state and realize the combination of economic growth and social development.

Bolivia continues to promote the establishment of a "good life socialism". President Evo Morales and other Party leaders put forward the idea of "good life socialism" on the basis of 
their "social socialism" and "Indian socialism". On the one hand, they reiterate the basic position of negating capitalism, on the other hand, elaborates on the connotation of "good life socialism. They believe that "capitalism is neither a solution to the problem nor a hope. We should not allow capitalism to bring more crises for future generations, and we should seek new solutions to capitalism." [4] In their view, "the good life socialism" is a kind of new socialism advocates, it's a harmony and well-being socialism, it's based on a better life. "Social group socialism" and "good life socialism" the purpose is to establish social justice, equality and a better life.

\section{B. The new dilemma faced by "Socialism of the 21st century" in Latin America countries.}

The living environment of "Socialism of the 21st century" in Latin American countries tends to be complex after the death of Hugo Chavez. Venezuela's ruling united by the socialist party has a weak grip on the state. It also has some negative effects on other leftist governments in Latin America. Venezuela and Latin American socialist movements suffered from huge losses when Chavez deaths in March 2013, "Socialism of the 21st century" in Latin American countries become turmoil. After 2014, the sharp decline in the price of oil and primary products in the international market caused a sharp decrease in income; Venezuela's economy is in recession. This opposition has taken advantage of rising public discontent to the government; the opposition has repeatedly struggled to force the ruling party to step down. Although Venezuela's leftwing ruling party still controls the four institutions of administration, justice, elections and civil rights, the prospects for long-term governance are dimming. Once Venezuela in the event of change ruling party, not only the "Socialism of the 21st century " construction process may be reversed, Ecuador, Bolivia's socialist practice will explore a negative impact, because these countries left-wing ruling party's support from Venezuela can be extracted ,they are ruling ability will be tested.

Secondly, since Raul Castro came to power, the relationship between Cuba and the United States has improved, that has changed the geopolitics of Latin America and changed the living environment of the "Socialism of the 21st century". In December 2014, Cuba and the United States announced the opening process of normalization of relations between the two countries, and restore the diplomatic relations. The "Socialism of the 21st century" in Latin America countries always had a strong anti-American tendency, especially against American hegemony and interference in Latin American affairs. Cuba is the traditional "base camp" of Latin American leftist forces and the spiritual leader of Latin American socialism. With the relations gradually improved by Cuba and the United States, the "Socialism of the 21st century" in Latin America countries may weaken anti-Americanism stance, the external environment may corresponding change.

Thirdly, the international environment of the "Socialism of the 21st century" in Latin America countries is more unfavorable. For one thing, the opposition to "Socialism of the 21st century" will not disappear. For a long time, both in Latin America and elsewhere, there is an opposition and hostility wants to " demonized " the "Socialism of the 21st century", some right-wing forces on criticized the "Socialism of the 21st century" is based on obsolete and outdated ideas, it's far away from the "open, freedom and prosperity", it's a way to "misery and misfortune"; The opposition Stressing that defeating the "Socialism of the 21st century" is a sense of responsibility, it's even called on the United States, Europe and Latin American "democracies" to strengthen unity and defeat the "Socialism of the 21st century". For another, the United States cracking down the leftist forces of Latin America through various channels, putting pressure on the left party. The United States can't agree with the "Socialism of the 21st century" in Latin America countries. He supporting the oppositions and trying to promote regime change in these countries. In addition, the regional environment of the "Socialism of the 21st century" in Latin America countries has deteriorated. Since late 2015, major changes have occurred in Latin America, Argentina, Brazil, changed their government, the country's new government criticized the Venezuela government and sympathetic the opposition which lead dissatisfaction of Venezuela government and increase the distrust between the Latin American countries.

Fourth, the social consequences of the recession in Latin America are more and more obvious. The economic downturn has led to decline in government revenues and social spending. Some social welfare programs have been blocked, unemployment is rising and poverty is rebounding. At the same time, popular discontent are spreading, social protests are increasing. In many countries, the situation of public security has deteriorated, the violence and crime become serious, and the insecurity of society has increased. Some of the middle classes that used to support the government have come to the opposite of the ruling party. Under these new social and economic conditions, many leftist parties in Latin America have deteriorated. The legitimacy of the ruling party has been increasingly questioned. 'In 2014, a massive social protest happened in Venezuela which cased ten people dead and hundreds injured. Since then, social discontent has sustained, social contradictions and confrontations have intensified, increasing the risk of political instability"[5]. Bolivia is a multiethnic country, with various vested interests and complicated social contradictions. Due to the economic downturn and loss of social spending, social discontent also increased and tends to be more protests, the social conflict is aggravating which impaired the legitimacy foundation of the ruling party; In February 2016, and Bolivia's ruling party lost a referendum. In Ecuador, anti-government rallies and protests are taking place. In Brazil's the left-wing ruling party is in a serious crisis of governance.

Fifth, in Venezuela, Ecuador, Bolivia and other left-wing ruling countries they implement multi-party system, therefor, the left-wing party facing more and more pressure and challenges from the opposition, the practice of "Socialism of the 21st century" in Latin America countries facing big resistance. Venezuela's ruling party and the opposition has big difference in ruling the country, the former supports socialism, advocates comprehensive national economic, social intervention operation and participatory democracy, emphasis on grassroots political mobilization, attaches great importance to the cooperation with developing countries; The latter one advocates a liberal, respect for the market position, to protect 
the interests of the private sector, the maintenance of representative democracy, strengthen system construction, to carry out the equilibrium diplomacy, to stop or to slash foreign aid, change the special relationship with Cuba. Venezuela's opposition severe criticize the "Bolivarian revolution" and "Socialism of the 21st century", try to change the current political and economic pattern, and tries to use various means to overthrow the left-wing government. The ruling party of Venezuela supports land reform, set up the cooperative and community committee, the state intervention in the economy, "Socialism of the 21st century", the Bolivarian alliance of America, but this measure is controversial, especially by interest groups and the conservative opposition. After Chavez's death, the opposition intensified. At present, the opposition control of the legislative power and put pressure on the government, this impede the construction of "Socialism of the 21st century".

\section{The possible trend of "Socialism of the 21st century" in Latin America countries}

Facing of the new difficulties and challenges, the Latin American left-wing Party leaders put forward some new ideas and elaborations. In the short term, the exploration of "socialism in the 21st century" in Latin America will not be smooth; it has great uncertainty in the future. But in the long way, the socialism foundation in Latin American is deep and still has room for further growth.

Faced by the political system, cultural tradition, internal and external factors, Socialism of the 21st century in Latin America cannot fundamentally solve the difficulties in all kinds, it's prospect has twists and uncertainty. Latin America's '21st century socialism" cannot fundamentally solve the problems that restrict the development of Latin America. "socialism in the 21st century" claims to achieved power through peaceful, legal way. The changes and improvements that socialism in the 21st century carries out have been made in the framework of the existing system. Even in Venezuela there is no transcendence and break through the framework of the existing political system, therefore it's difficult to fundamentally solve the country and the region's problems. In the long run, the foundations of its social support will damage, and will losing some popular support, which will inevitably increase the uncertainty of its practical prospects.

First, non-mainstream and populist tendencies also bring some uncertainty to socialism in the 21st century in Latin America. The Latin American countries are closer to the European and American countries in their ideological beliefs, customs, values, political ideas and ideologies. The ideas of freedom, democracy, human rights and multi-party system in European and American countries also occupy the mainstream in Latin America. The concept and practice of socialism has not become the consensus of the whole society, and most people prefer a moderate middle way. Since the beginning of the new century, the influence of "socialism in the 21st century" has limited to a few Latin American countries, such as Venezuela, and the main ideology and the main practice in the whole region didn't have the characterizes of socialism. Even in Venezuela, there are many people who still have doubts about the practice of socialism. In Ecuador and Bolivia, socialism is just a slogan of the left-wing ruling party, and it's not a national platform. All these constitute a great restriction on the practice of socialism. In addition, the tendency of populism in "21st century socialism" will be difficult to eliminate, it will also aggravate the uncertainty of social practice. American scholar Peter Lars though that," one of the most significant innovation in Venezuela and "socialism in the 21st century" is fusion the Bolivar's nationalism, Marxism in the 20th century, and the Latin American populism. It is risky to rely on the charismatic leaders, once the charismatic leader is untested, the social practice will suffer from irreparable damages"[6].

Second, the external threat increases the risk and uncertainty of Latin America's "21st-century socialism". The practice of "socialism in the 21st century" in Latin America encounters has many external obstacles. As noted earlier, the United States opposes the "socialism in the 21st century", he pressuring Latin American left countries. Supported by the United States, opposition groups such as Venezuela and Bolivia gathering strength to compete with the left-wing ruling party. Latin American scholars believe that 'the United States has been trying to create disunity among Latin American countries to maintain the "fragmentation" of Latin American. "[7]The United States wants to use the economic difficulties to pressuring the left-wing ruling countries such as Venezuela, Bolivia and Ecuador, prompting the opposition came to power. Once the opposition in power, the practice of "socialism in the 21st century" in Latin America will at risk of reversal or disruption.

\section{CONCLUSION}

Although the practice of "socialism in the 21st century" in Latin America will not be smoothly, its social foundation is still solid; it also has broad appeal and influence. In the long run, socialism still has further growth in Latin America. Traditionally, Latin American countries didn't pay attention to social reform, the phenomenon of "social exclusion" and "marginalization" has been serious. In recent years, the poverty is reduced, the income distribution is improve, and social justice has promote, but the unfair distribution is still serious, abnormal poverty, social wealth is highly concentrated in the hands of a few people, people still have a strong sense of injustice. Related to the survey, most people think that the income distribution in the region is unfair, $60 \%$ of people think that the political system and the state institutions are unreasonable. The public's need is closer to the left-wing parties and the socialist; they have strong desire to change the status quo, these providing a broad social foundation for the development of socialism. socialist practice in Latin American is facing same periodic setbacks, but as a kind of value and policy choices, socialism in Latin America still has great influence and strong vitality, it will further growth.

\section{REFERENCES}

[1] Heinz Dieterich, Der Sozialismus des 21. Jahrhunderts - Wirtschaft, Gesellschaft und Demokratie nach dem globalen Kapitalismus, Einleitung Socialism of the 21st Century - Economy, Society, and Democracy in the era of global Capitalism, Introduction. 
[2] JamesPetras, Latin American socialis m in the historical perspective,[J] Foreign Theoretical Trends, 2010. . (In Chinese)

[3] He Qin, Crisis, consensus and action -- the socialist party of venezuela under the test of government risk.[J] Lat in American Studies,Jenuray 2015. (In Chinese)

[4] Yuan Dongzhen.New development of "socialis m in the 21st century"in Latin American.[M].World socialism tracking research report(20152016), Social sciences academic press, 2016, pp. 310-319. . (In Chinese)
[5] Xu Shicheng, A preliminary analysis of chavez's "21st century socialism"[J] Studies on Marxism, October 2010 . (In Chinese)

[6] Wang Peng, The thought and practice of "socialis $m$ in the 21st century" in venezuela.[J] Latin American Studies,June 2009. . (In Chinese)

[7] Zhang Jing Xia, Bi Xiao Guang, Research on Fidel Castro's thought about party building[J] Studies on Marxism, June 2010. (In Chinese) 